Article

\title{
The Impact of Sustainable Sourcing on Customer Perceptions: Association by Guilt from Scandals in Local vs. Offshore Sourcing Countries
}

\author{
Claire Veit ${ }^{1}$, Wim Lambrechts ${ }^{2, *} \mathbb{1}$, Lieven Quintens ${ }^{1}$ and Janjaap Semeijn ${ }^{1}$ \\ 1 School of Business and Economics, Maastricht University, Tongersestraat 53, 6211 LM Maastricht, \\ The Netherlands; c.veit@alumni.maastrichtuniversity.nl (C.V.); l.quintens@maastrichtuniversity.nl (L.Q.); \\ j.semeijn@maastrichtuniversity.nl (J.S.) \\ 2 Department of Marketing and Supply Chain Management, Open University of The Netherlands, \\ P.O. Box 2960, 6401 DL Heerlen, The Netherlands \\ * Correspondence: wim.lambrechts@ou.nl; Tel.: +31-45-576-2826
}

Received: 16 May 2018; Accepted: 16 July 2018; Published: 18 July 2018

\begin{abstract}
This study analyzes whether customer perceptions towards sustainability are affected by a company's country of origin and sourcing strategies. This study builds upon the literature regarding customer interest in sustainable products. It adds the country of origin to the link between customer and company, and analyzes if and how customer perceptions change when they are introduced to a sustainability scandal, hence analyzing possible 'association by guilt'. It compares their reactions to offshore scandals and to local scandals, therefore taking psychic distance as an important variable into consideration. Customer perceptions of company sustainability was found to have an impact on purchasing behavior. Findings show that perceptions are influenced by psychic distance. Furthermore, companies should take into account the risk of association by guilt when developing their global sourcing strategies.
\end{abstract}

Keywords: customer perception; psychic distance; supply chain; sustainability; sourcing strategies

\section{Introduction}

In a world of scarce resources companies have come to realize that it is not simply a trend but a responsibility to act more sustainably [1]. Irresponsible, unethical, or opportunistic behavior has become detrimental for a company's reputation. At the same time, in order to stay competitive, companies are expanding their businesses globally and outsource non-core activities [2]. They build supply chains that consist of a network connecting different partners, countries, and consumers. This growing complexity leads to considerable challenges for sustainable sourcing strategies. One strategy to pursue sustainability is to re-shore [3]. Reshoring brings offshored business back home and may cater to sustainability goals. Growing news coverage of supply chain scandals leads to increasing customer interest in sustainability. These scandals mainly occur at the place of production-mostly developing countries-but they cause public outcry in the developed world, where the majority of products is sold [4]. Often, the production process has been outsourced to factories belonging to the supplier. This vertical disintegration means that the focal company, which sells the product under their brand name to (Western) consumers, is legally not responsible for the conditions at the point of production. Nevertheless, scandals may automatically be associated with the focal company. Molet et al. [5] call this phenomenon 'association by guilt'; when two parties are linked to each other, the negative reputation of one can impair the reputation of the other. 
This form of supply chain contagion might trigger customer awareness of sustainability and demand for more transparency. Supply Chain Transparency includes vertical as well as horizontal transparency so that all of the stakeholders and supply chain players have better access to corporate supply chain information [6]. In order to create transparency, a firm needs to increase control over outsourced services. One approach is to establish a set of guidelines that suppliers need to follow, concerning child labor, safe work places, or waste disposal. This approach is already adopted by multinational companies, like IKEA and Danone [7]. Moreover, sharing positive information about sustainability measures is becoming a standard for being competitive [8]. Thus, company sustainability rankings have become a popular tool for benchmarking (e.g., Dow Jones Sustainability Index, Global 100, Thomson Reuters Environmental, Social and Governance Indices). Investments in sustainability could also be justified by customer demands for more sustainable behavior [4]. It is however unclear whether they really care about sustainability along the entire supply chain or only at the point of sale when purchasing from the focal company.

This study takes a closer look at customer perception of company sustainability and the link to supplier sustainability by taking into consideration the role of countries. Thus, it adds country influence to the existing literature about company-customer relations. The following research questions (RQ) are focused upon:

RQ1: Do the countries of origin of both the focal company and supplier influence the customer purchasing behavior?

RQ2: Is customer perception of the focal company sustainability linked to distance and perception of country sustainability?

Based on the literature regarding sustainable supply chain management, customer perceptions, and country sustainability, eight hypotheses have been developed. Data have been gathered through an experimental research design with four separate types of questionnaires. This paper is organized as follows: Section 2 provides the literature review, the hypotheses, and research model. Section 3 describes the methods, while Section 4 presents the results, including reliability and validity issues. Section 5 discusses the results of this study in light of previous insights from the literature. Section 6 concludes this paper by providing theoretical contributions of this study, managerial recommendations, as well as possible limitations of the study and potential pathways for further research.

\section{Literature Review and Hypotheses}

\subsection{Sustainable Supply Chain Strategies}

In the context of Supply Chain Management (SCM), the business case to integrate sustainability and foster sustainable supply chains has been developed, since sustainability becomes a growing demand within global business settings [9]. Different definitions and interpretations are available for Sustainable Supply Chain Management (SSCM), ranging from a narrow focus towards environmental issues (also referred to as Green Supply Chain Management, GSCM), to a holistic interpretation of economic, environmental, social, and ethical aspects in the supply chain [10]. One of the working definitions of SSCM, which is adopted in the context of this paper as well, is: "The integration of sustainable development and supply chain management [in which] by merging these two concepts, environmental and social aspects along the supply chain have to be taken into account, thereby avoiding related problems, but also looking at more sustainable products and processes" [11] (p. 132). Different conceptual frameworks regarding SSCM have been presented in the literature, focusing on triggers, risks and performance issues, and sustainable products [12], or on triple bottom line approaches [13]. In the latter, focus is set on finding a balance between economic, environmental, and social performance, however Carter and Rogers [14] state that they "are not suggesting that organizations blithely undertake social and environmental goals relating to the supply chain", thereby referring to the extra costs that these goals would bring to an organization [14] (p. 369). 
Such interpretations, in which SSCM is reduced to the supremacy of financial and economic dimensions over environmental and social dimensions, are however criticized [15]: "the question of how to create truly sustainable supply chains remains unanswered" [15] (p. 44). A 'truly sustainable supply chain' might then be defined as follows: "To be truly sustainable a supply chain would at worst do no net harm to natural or social systems while still producing a profit over an extended period of time; a truly sustainable supply chain could, customers willing, continue to do business forever" [16] (p. 38). Traditionally, the economic dimension received more attention in business (e.g., [17]), but as customers have emerged as a driving force, more attention should be paid to environmental and social issues. This approach is supported by research stating that customers are more interested in these two aspects, and therefore, firms concentrating on them will see a positive impact on their overall sustainability performance $[4,18]$.

The growing awareness of negative effects due to unsustainable behavior results in the demand on firms to take responsibility. Emotions may play a major role in sustainability scandals. In the last few years, many sustainability scandals linked to companies have been exposed. Well known cases include the Rana Plaza factory collapse, which was linked to Primark [19], child labor at a factory for Nike products, as well as harmful ingredients in Mattel products [4]. While in the past, this was mainly communicated via TV and newspapers, today's social networks and media spread information faster than ever and reach people all over the world [20]. This resulted in a demand for transparency along the entire supply chain, and increased attention towards the effects of individual processes on sustainability [21].

The focus on sustainability shifts from the individual firm level to the entire supply chain. Different shoring and sourcing strategies have been developed throughout the years, each having a positive or negative effect on supply chain sustainability. One strategy is to wholly own the supply chain by the focal company, such that every link of the chain is located in proximity to the other. When parts of the supply chain are moved to other countries but are still operated by the focal company, this strategy is called offshoring [22]. Whenever a service is purchased from a supply chain partner, it is no longer wholly owned by the focal company and we talk about outsourcing [23]. Outsourcing can take place in the same country or it may involve going abroad, which is then called offshore outsourcing. Reasons for offshoring are lower wages, extended working hours due to the presence in different time zones, or proximity to important resources [22]. Offshore outsourcing causes negative environmental impacts, such as an increase in (global) carbon emissions [24] and agricultural land grab in impoverished regions [25].

The increasing complexity of global networks and sourcing strategies are challenging companies to act sustainably. Production processes are often spread across continents and the supply chain partners are linked by the flow of information, material, and capital [12]. Different factors influence the supply chain and lead to increased uncertainty, which needs to be understood and managed [26], and global sourcing should be interpreted within the context of sustainability [27]. Each process step has environmental and societal effects and often it is the focal company that will be held responsible for these outcomes. This poses a challenge for the focal company to manage processes within their supply chain, including relations with direct, second, and third tier suppliers. Therefore, the company has to ensure that corporate sustainability is practiced internally and that these values are followed equally by their supply chain partners [12].

Two more strategies gained popularity in recent years. Reshoring aims to bring the business back home, especially manufacturing. These initiatives are responses to the decreasing income gap between the West and its offshore locations and a growing supply chain complexity [28], as well as the result of economic crisis and customer demand for flexibility and improved cost performance [29]. Similarly, nearshoring moves the business not fully home but closer to home, i.e., to a nearby country [3]. In order to ensure sustainability at the supplier, effective supplier management needs to be in place. Therefore, the reason to offshore in order to save costs has lost in importance, while closer ties with the supplier, made possible by geographical proximity, have become a priority. However, the process of moving 
offices and people as well as creating new ties is costly. Different initiatives have been presented to encourage reshoring and local sourcing, such as a framework to 'right-shore', which considers the initial decision making process to offshore and then re-evaluates that decision [30], sustainability factors for reshoring [3], and carbon footprint tax [31]. Local businesses and firms with global businesses also apply different sustainability strategies. For local firms, traditional supply management (SM) is a sufficient prerequisite for sustainable behavior. For global companies, in addition to SM, SSCM has to be introduced to show significant improvement in sustainability performance. Adopting global sourcing strategies does increase supply chain complexity, but may at the same time push a company to introduce SM and SSCM, improving environmental and social performance [4].

\subsection{Customer Demand and Perception of Sustainability}

In the literature, different drivers to integrate sustainability are identified, such as compliance to laws and regulations. More and more however, customers demand sustainability and companies find ways to meet this demand, e.g., by analyzing and lowering product carbon footprints [32]. Attention towards sustainability can lead to an increase in sales and a growing customer base. This has resulted in companies reporting on their Corporate Social Responsibility (CSR) [33]. Also, the attention to supply chain scandals leads to increasing customer demand towards sustainability and transparency [4].

An important aspect of customer demand is the perception of the focal company and its supply chain. Irresponsible behavior of one supply chain partner can have a negative impact on the reputation of the remaining partners. Following Molet et al. [5], an individual will be evaluated negatively when associated with someone else who has a bad reputation. This is called 'association by guilt' and can be compared to a supply chain contagion [5]. Referring back to the differentiation between offshoring and outsourcing, this concept indicates that outsourcing a sustainably weak part does not necessarily increase the reputation of the focal company's sustainability. It will still be associated with the focal company's supply chain, and thus, whenever a problem is identified at a supplier, this can also negatively impact the focal company. The opposite, association by honor or the "halo effect', is also possible. Products sold by companies that engage in social initiatives will automatically be perceived as more valuable or sustainable even though the product itself might have no link to any of the initiatives [34]. Often, this is the main reason for businesses to engage in CSR. It is assumed that the closer a customer is to a company, whether considering spatial or social distance, the stronger is the effect that corporate social performance may have on customer perception, as well as customer willingness to continue buying from that firm and even pay a price premium for sustainable products [35]. This leads to the following hypotheses:

Hypothesis 1 (H1). Customer perception of a company's sustainability is expected to have a direct impact on willingness to continue buying from the focal company.

Hypothesis 2 (H2). Customer perception of a company's sustainability is expected to have a direct impact on willingness to pay a price premium for sustainable products from the focal company.

On the other hand, it is suggested that consumers have adopted a globalized perception. CSR initiatives to them are global initiatives, and therefore are not necessarily linked to an individual country [18]. Further, people tend to project their own traits onto others, which is called 'Spontaneous Trait Transference' [5]. This could mean that consumers who act sustainably might expect firms to act the same. For this study, it is important to consider whether the transference of traits differs with distance. Accordingly, it is valuable for companies to know what is important to their customers and which initiatives can evoke the greatest emotions and identification with the cause. Regarding age and gender characteristics, a report by Morgan Stanley [36] has also taken a look at the influence of age or gender. It shows that Millennials, people born around 1980-1999, and especially female 
customers are interested in sustainability [36]. The dispositions regarding customer interest lead to the following hypotheses:

Hypothesis 3 (H3). Customer interest in sustainability has a moderating effect on the link between customer perception of a company's sustainability and the willingness to continue buying from the focal company.

Hypothesis 4 (H4). Customer interest in sustainability has a moderating effect on the link between customer perception of a company's sustainability and the willingness to pay a price premium for sustainable products from the focal company.

Furthermore, business oriented CSR increases trust in the company while philanthropic CSR supports the consumer's identification with the company [37]. Accordingly, satisfaction, trust, and identification are important values that contribute to strong customer support [18]. If the relationship between company and customer scores is low on these three values, then there is a greater chance of the customer boycotting the brand in case of a scandal [38] or switching to a different brand [39]. The (spatial, social) distance to the focal company has an effect on customer perception, willingness to continue buying, and even pay a price premium [35]. Distance to the company surpasses the spatial element and comprises other factors, such as linguistic, cultural, economic, and political differences. Therefore, this study interprets distance as psychic distance, as defined by Johanson and Vahlne [40], and further elaborated upon in international outsourcing context [41]. For this study, it is assumed that customers identify more easily with companies of low psychic distance, and, thus, are more loyal to those than to foreign companies of high psychic distance:

Hypothesis 5 (H5). Psychic distance is expected to have a direct impact on customer perception of a company's sustainability.

Hypothesis 6 (H6). Low psychic distance of the supplier's country of origin is expected to have a direct positive impact on customer perception of a company's sustainability.

Hypothesis 7 (H7). Low psychic distance of the focal company's country of origin is expected to have a direct positive impact on customer perception of a company's sustainability.

The strong focus on the link between customer and company has led to the question whether customers are purely interested in the point of sale, and thus, only the sustainability of the focal company. This would indicate that consumers take a great interest in corporate social performance of businesses with low psychic distance, but are likely to ignore the rest of the supply chain. Further, consumers might show less interest in sustainability when there is high psychic distance or intuitively evaluate these companies as less sustainable. Therefore, the discussion about customer-company is extended by 'country' and it suggests that customer perception of sustainability can be influenced on all three levels.

Country sustainability indices, like the one for companies, vary in size as well as in indicators. Some of them only measure the ecological footprint, or, like the Human Development Index [42], mostly social and economic sustainability. One index measuring all three indicators of the triple bottom line is the Sustainable Society Index (SSI). The SSI analyzes 151 countries and includes 21 indicators in three categories: economic wellbeing (5), human wellbeing (7), and environmental wellbeing (9) [43]. It is unclear whether there is a direct relationship between environmental and social factors [42]. The Sustainable Society Foundation (SSF), however, has found at least some negative correlation in their SSI, and therefore decided to publish separate rankings for each indicator instead of an overall sustainability index [43]. For instance, while Mozambique as well as the Central African Republic score very low on human wellbeing, they can both be found in the top 10 of the environmental index. 
Corporate sustainability efforts are related to a country's national culture, more specifically the degree of individualism and uncertainty avoidance [44]. Moreover, costumer perception of a country's industry and corporate landscape impact their perception of that country's sustainability [45]. Therefore, this study takes a closer look at a country's effects on consumer opinion about company sustainability. The question is, whether the sustainability of individual sourcing countries and the focal company's country of origin influence customer perception of the brand's sustainability. This is reflected in the formulation of the following hypothesis:

Hypothesis 8 (H8). Customer perception of a country's sustainability is expected to have an impact on customer perception of the company's sustainability, when associated with that country.

Table 1 presents an overview of all the hypotheses analyzed in this study, as well as the main sources from which they are derived; Figure 1 provides the research model for this study.

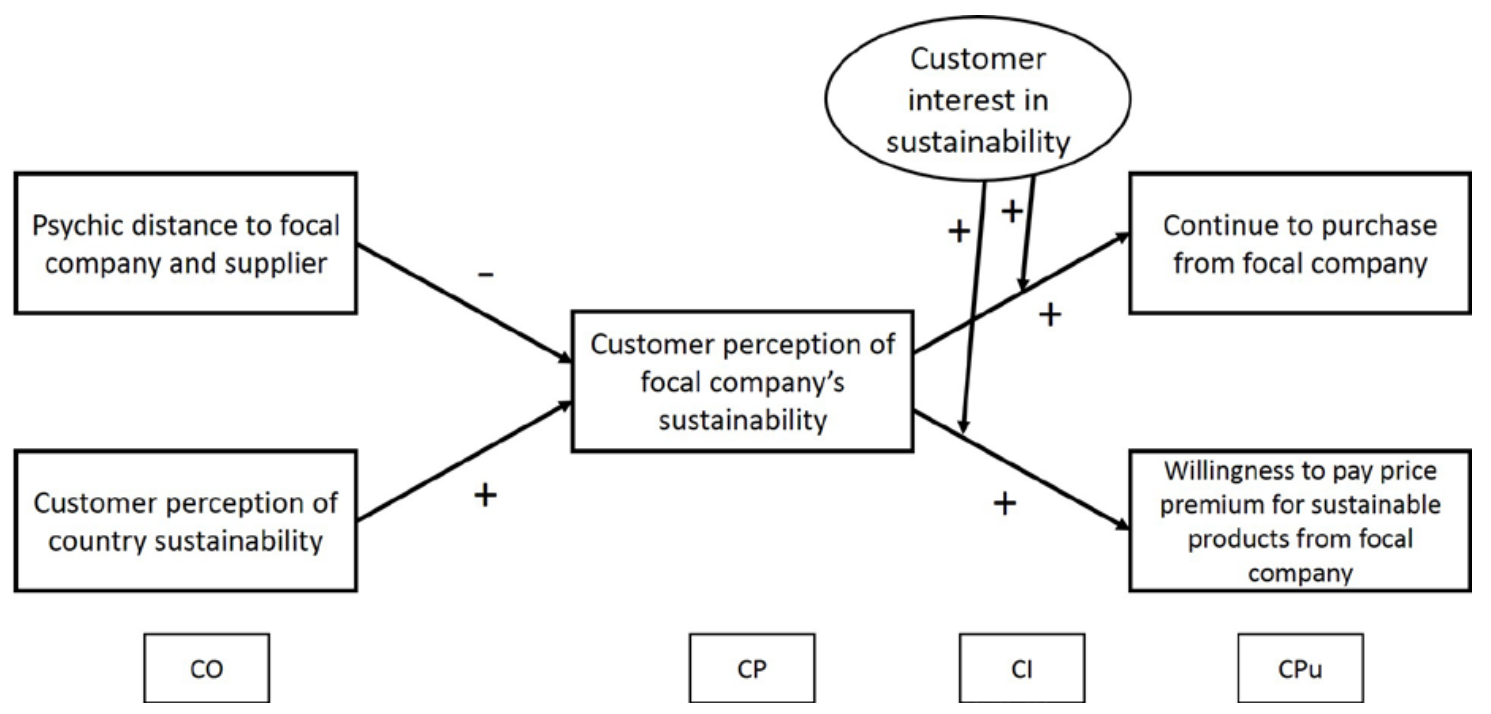

Figure 1. Research model (Legend: CO: Country attributes; CP: Customer Perception; CI: Customer Interest; $\mathrm{CPu}$ : Customer Purchasing behavior).

Table 1. Hypotheses.

\begin{tabular}{lc}
\hline \multicolumn{1}{c}{ Hypothesis } & Derived from \\
\hline $\begin{array}{l}\text { H1: Customer perception of a company's sustainability is expected to have a direct impact on willingness } \\
\text { to continue buying from the focal company }\end{array}$ & {$[5,34,35]$} \\
\hline $\begin{array}{l}\text { H2: Customer perception of a company's sustainability is expected to have a direct impact on willingness } \\
\text { to pay a price premium for sustainable products from the focal company }\end{array}$ & {$[5,34,35]$} \\
\hline $\begin{array}{l}\text { H3: Customer interest in sustainability has a moderating effect on the link between customer perception } \\
\text { of a company's sustainability and the willingness to continue buying from the focal company }\end{array}$ & {$[5,18,35]$} \\
\hline $\begin{array}{l}\text { H4: Customer interest in sustainability has a moderating effect on the link between customer perception } \\
\text { of a company's sustainability and the willingness to pay a price premium for sustainable products from } \\
\text { the focal company }\end{array}$ & {$[5,18,35]$} \\
\hline $\begin{array}{l}\text { H5: Psychic distance is expected to have a direct impact on customer perception of a } \\
\text { company's sustainability }\end{array}$ & {$[18,35,37-41]$} \\
\hline $\begin{array}{l}\text { H6: Low psychic distance of the supplier's country of origin is expected to have a direct positive impact } \\
\text { on customer perception of a company's sustainability }\end{array}$ & {$[18,35,37-41]$} \\
\hline $\begin{array}{l}\text { H7: Low psychic distance of the focal company's country of origin is expected to have a direct positive } \\
\text { impact on customer perception of a company's sustainability }\end{array}$ & {$[18,35,37-41]$} \\
\hline $\begin{array}{l}\text { H8: Customer perception of a country's sustainability is expected to have an impact on customer } \\
\text { perception of the company's sustainability, when associated with that country }\end{array}$ & {$[44,45]$} \\
\hline
\end{tabular}




\section{Methods}

\subsection{Research Setting, Data Collection and Survey Instrument Design}

The study aims to explore the effect of psychic distance to customer perception of sustainability of the focal company. As the research design is exploratory in nature, different single-item scales were used for the questionnaire. The reasons were twofold. First, the study did not focus on construct development, and second, the questionnaire should be as short as possible so as not to discourage respondents to fill out the survey. Only the "consumer interest in sustainability" scale was considered to be a true scale. The reason it was opted to include this scale is that in this research, the customer interest in sustainability is crucial and many different approaches are reported in the literature. The approach that fitted best with the scope of this research was based on the Morgan Stanley report [36]. Furthermore, the variable "perception of a country's sustainability" was obtained via the sum of the composing items.

This study follows an experimental research design, in which four different types of questionnaires were created to test the hypotheses. The questionnaires contained an identical case and identical questions, but the countries of origin of the companies differed across the survey types. The surveys were aimed at respondents from Western Europe to keep a similar psychic distance between the respondent and the focal company and supplier countries mentioned in the case. The surveys were created and shared via the online platform 'Free Online Surveys', and shared via social media. Due to a snowball effect, this also yielded many responses from non-European countries. Specific attention is required with respect to the online sharing of questionnaires, as this might lead to bias in respondents. However, the study sets up an exploratory approach in order to explore the importance of psychic distance, not in testing differences in customer groups. Table 2 provides the demographics of the respondents; it shows a disproportionate amount of German respondents. As this might impact the results, additional tests were performed to see whether or not German/European/Non-European respondents had different perceptions. Apart from the question regarding their willingness to pay a price premium and the question if people would like to know how sustainably the product was made, none of the questions differed between Germans and non-Germans. Therefore, there is little evidence that the responses are biased.

The case presents a negative situation that is caused by the supplier of the focal company. It intends to find out whether this negative situation will be projected onto the focal company by the respondents. As the company is fictitious and presented negatively, the answer is expected to be influenced through 'association by guilt' $[5,34]$. The case introduced in the surveys focused on unsustainable poultry production, because it is a pressing issue locally (Germany), as well as abroad (Indonesia). The focal company in the survey cases is either Japanese or Spanish (because of the consumption patterns in these countries), while the supplier is located in Germany or Indonesia. Thus, it resulted in a total of four combinations (Table 4) ranging from very low psychic distance (country combination 2) to very high psychic distance (country combination 3). A description of the case is provided in Box 1.

The questionnaire was prepared in three stages. First, a thorough literature research provided the basis for creating questions and led the authors to provide respondents with a case in order to test their reactions to unsustainable production. In order to rule out that a case would lead to biased responses to later, more general questions about sustainability, the second stage of preparation consisted of a pilot phase. Here, the questionnaire was distributed to two groups of students at a German university: one group received the full questionnaire; the other group received a questionnaire without a case. As the answers did not show a significant difference between the groups, it was decided to include a case in the final survey. In the third stage, the questionnaire was proof-read by experts from academia and business in order to avoid biases and incomprehensibility. A detailed description of the questionnaire is provided in Appendix A. 
Table 2. Descriptives.

\begin{tabular}{ccccc}
\hline \multirow{2}{*}{ Category } & \multicolumn{4}{c}{ Country Combination } \\
\cline { 2 - 5 } & $\mathbf{( 1 )}$ & $\mathbf{( 2 )}$ & $\mathbf{( 3 )}$ & $\mathbf{( 4 )}$ \\
\hline \#Respondents & 34 & 32 & 31 & 32 \\
Male & $38.2 \%$ & $40.6 \%$ & $35.5 \%$ & $50 \%$ \\
Female & $61.8 \%$ & $59.4 \%$ & $64.5 \%$ & $50 \%$ \\
Average Age & 24 & 24 & 24 & 36 \\
German & $64.7 \%$ & $78.1 \%$ & $90.3 \%$ & $84.4 \%$ \\
Dutch & $23.5 \%$ & $18.8 \%$ & $3.2 \%$ & $3.1 \%$ \\
French & $2.9 \%$ & $3.1 \%$ & $3.2 \%$ & $0 \%$ \\
British & $5.9 \%$ & $0 \%$ & $3.2 \%$ & $9.4 \%$ \\
Irish & $2.9 \%$ & $0 \%$ & $0 \%$ & $0 \%$ \\
Scottish & $0 \%$ & $0 \%$ & $0 \%$ & $3.1 \%$ \\
\hline
\end{tabular}

Legend: (1): Japan_Germany; (2): Spain_Germany; (3): Japan_Indonesia; and, (4): Spain_Indonesia.

Box 1. Description of the case of poultry production.

[company name] ${ }^{*}$, [country] ${ }^{* *}$
[company name] uses poultry from mega chicken factory farms in [country] and sells its products to various
supermarkets. There are several abuses that have been reported lately: animal cruelty, unsustainable feeding
sources, contamination of groundwater.
Unlike more ethically-produced poultry, the chicken are kept in very dense farms with no space to move.
Sick animals are rarely treated. Moreover, in order to keep barns disease-free, antibiotics are often used
preventively. This leads to the development of antibiotic-resistant bacteria, which will eventually pose a serious
problem to humans when diseases are no longer treatable.
Another point is that the feed is produced in a way that drives deforestation and harms the environment.
However, not only the feed production but also the feed digestion poses a great threat: the poultry dung is left
to seep into the groundwater which impacts the nearby neighborhoods. Once the groundwater is contaminated,
animals as well as humans can be affected through diseases; even for flower watering and irrigation purposes
the water will become unusable.
*Company name was fictional
* Country was either Japan or Spain for the focal company; Germany or Indonesia for the supplier

\subsection{Measurements}

Table 3 provides an overview of survey constructs. Country attributes consists of psychic distance between respondent and country as well as respondent perception of country sustainability. Research suggests that people may show stronger support for local than foreign companies, but this hypothesis is not supported [18]. One reason could be that perception of CSR is not directly dependent on the country of origin. Rather, it might be influenced by the perceived honesty of intentions and the trust of customers in a company. Trust however may vary due to the countries in which CSR is implemented. One possible reason is that trait transference of good faith and trustworthiness might be harder to apply the more foreign and unknown that a company or country is. Customer purchasing behavior $(\mathrm{CPu})$ is measured as a (possible) reaction to the case. It is analyzed whether the customer perception (CP) of the company, which is hypothesized to be influenced by psychic distance and the personal assessment of country sustainability, has an impact on the customer's buying behavior $[5,34]$. It considers whether customers would simply continue to buy from this brand (CPu1) or would even pay a price premium if the brand would sell sustainable produce $(\mathrm{CPu} 2)[18,35]$. In addition, a closer look is taken at the mediating role that Customer Interest in sustainability (CI) might play. Here, three items refer to the case and three to general preferences towards local vs foreign products. 
Table 3. Survey Constructs.

\begin{tabular}{cc}
\hline Construct & Reference \\
\hline Psychic Distance & {$[18,35]$} \\
Customer Perception $(\mathrm{CP})$ & {$[5,34]$} \\
Customer Purchasing behavior $(\mathrm{CPu})$ & {$[5,18,34,35]$} \\
Customer Interest $(\mathrm{CI})$ & {$[36]$} \\
Case & Indonesia: $[46] ;$ Germany: [47] \\
\hline
\end{tabular}

\section{Results}

The analysis of the hypotheses is done with IBM's SPSS software. Normality is assumed as each country combination in the survey received $>30$ responses. First, the model is tested for reliability by calculating each construct's Cronbach alpha. In some cases inconsistency was found, therefore it was decided to reduce the number of items or split the construct. Next, a principal component analysis (PCA) has been performed to test construct validity [48], the results showed whether the combination of items is correct or whether additional factors can be identified. Overall, the results are satisfactory. For the hypothesis testing, items are first tested for correlation. This aims at testing possible relationship between the customer purchasing behavior $(\mathrm{CPu})$ items and whether the earlier decision to split and test them separately was correct. For $\mathrm{H} 1$ and $\mathrm{H} 2$, a regression tested whether customer perception is a predictor for customer purchasing behavior. A simple linear regression is used as there was only one predictor variable (customer perception) [49]. Next, a partial correlation test calculates the moderating effect of customer interest on the link between customer perception and customer purchasing behavior (H3; H4). For partial correlation, variables need to be continuous; therefore, this study would violate this assumption. However, Bortz, Lienert, and Boehnke [50] suggest that satisfactory results can still be achieved. For H5-H7, four independent groups are compared, and a one-way between groups ANOVA helps to test for significant differences. Finally, the impact of customer perception of country sustainability on his/her perception of the company's sustainability (H8) is tested with a linear regression. The following sections explain the procedure and the results in more detail.

\subsection{Reliability and Validity}

Every construct is tested for reliability by checking its Cronbach alpha, a valid alpha being $\geq 0.7$. In some constructs this is not the case, and thus, the Inter-Item Correlation Matrix has to be checked for low correlation values. Items with values $<0.3$ are taken out of the group. Another way to detect an unfit item is to look at the 'Alpha if Item Deleted' table to see the impact of each item when removed from the scale. Table 4 shows the final Cronbach alphas for the 'Customer Interest in Sustainability' (CI) scale. The 'Customer Perception of Company Sustainability' (CP) scale was reduced to one item; "company $\mathrm{XY}$ is a sustainable company", and thus no reliability check is necessary. 'Customer Purchasing Behavior' $(\mathrm{CPu})$ scores a Cronbach alpha $<0.7$ for every country combination, and therefore, it is reduced and split into two items testing the effect of company perception on customer purchasing decisions separately (CPu1; CPu2). 'Customer Perception of Country Sustainability' only achieves a Cronbach Alpha $>0.7$ in country combination (1). It is decided to test the effect of focal company country and supplier country one by one, thereby enabling a comparison between the two items.

Table 4. Reliability Test of the Customer Interest Scale (CI).

\begin{tabular}{cc}
\hline Country Combination & Cronbach Alpha \\
\hline (1) Japan_Germany & 0.816 \\
(2) Spain_Germany & 0.878 \\
(3) Japan_Indonesia & 0.799 \\
(4) Spain_Indonesia & 0.9 \\
\hline
\end{tabular}


A PCA is performed in order to test whether the current constructs show more underlying linear combinations than assumed. There are two conditions to see whether such factorial analysis is appropriate: the Kaiser-Meyer-Olkin value, which should exceed 0.6 [51], and the Bartlett's Test of Sphericity [52], which reports statistical significance. The customer interest scores significant results for every country combination, and therefore, is analyzed for factors. Except for country combination (3), which shows two possible components, the scree test and parallel analysis result in only one component with a total initial Eigenvalue $>1$. This supports the strength of the scale and it is decided to keep one component for country combination (3) too, to ensure comparability between the groups. Therefore, the grouping proves to be appropriate. On this basis, the next section describes the results of the hypothesis testing.

\subsection{Results}

The hypotheses are tested within groups. Only for the psychic distance item, a one-way ANOVA is performed in a master file containing all of the responses to test the variance between groups. First, correlation between the two items of the customer purchasing behavior scale is calculated again, to see whether the decision to test them separately is appropriate (Table 5). No significant correlation is present. Thus, the decision is supported.

Table 5. Customer purchasing behavior ${ }^{* * *}$ significant at $p<0.01 ;{ }^{* *}$ significant at $p<0.05 ;{ }^{*}$ significant at $p<0.1)$.

\begin{tabular}{cccccc}
\hline Group & CPu Item & $\mathbf{R}$ & $\mathbf{R}^{\mathbf{2}}$ & B (Constant) & B (Independent Variable) \\
\hline \multirow{2}{*}{ (1) Japan_Germany } & CPu1 & 0.347 & 0.120 & 1.263 & $0.370^{* *}$ \\
& CPu2 & 0.065 & 0.004 & 3.754 & -0.099 \\
\hline \multirow{2}{*}{ (2) Spain_Germany } & CPu1 & 0.792 & 0.628 & 0.684 & $0.693^{* * *}$ \\
& CPu2 & 0.156 & 0.024 & 3.649 & -0.158 \\
\hline \multirow{2}{*}{ (3) Japan_Indonesia } & CPu1 & 0.326 & 0.106 & 1.250 & $0.375^{*}$ \\
& CPu2 & 0.013 & 0.000 & 3.553 & 0.018 \\
\hline \multirow{2}{*}{ (4) Spain_Indonesia } & CPu1 & 0.606 & 0.367 & 0.630 & $0.699^{* * *}$ \\
& CPu2 & 0.331 & 0.110 & 4.417 & $-0.454^{*}$ \\
\hline
\end{tabular}

Legend: $\mathrm{CPu}$ : customer purchasing behavior; $\mathrm{CPu} 1$ : continue purchasing; $\mathrm{CPu} 2$ : willingness to pay a price premium.

Next, a linear regression helps to test $\mathrm{H} 1$ and H2. H1 is supported for country combinations (1), (2), and (4). For country combination (3), the results only show marginal significance. The tests show no support for $\mathrm{H} 2$ throughout country combinations (1)-(3), but do show marginal significance for (4). Therefore, it can be concluded that the perception of a company's sustainability is a prerequisite to the decision on whether to continue buying from that firm (Customer perception-customer purchasing behavior (CPu1)). However, there is no or very little evidence that it is a prerequisite to the decision to pay a price premium for sustainable products (Customer perception-customer purchasing behavior (CPu2)).

Partial correlation is used to explore the relationship between perceived company sustainability and customer purchasing behavior, while controlling for scores on the customer interest scale ( $\mathrm{H} 3-\mathrm{H} 4)$. There are weak, partial correlation coefficients for country combinations (1) and (3) and strong partial correlation coefficients for country combinations (2) and (4), controlling for customer interest on customer purchasing behavior (continue buying, $\mathrm{CPu} 1$ ). For the willingness to pay a price premium (CPu2) only results for country combination (4) are calculated as the other groups showed no link between customer perception and willingness to pay a price premium in the first place. Here, the partial correlation coefficients are also weak. An inspection of the zero order correlation suggests that controlling for customer interest has very little effect on the strength of the relationship of customer perception-customer purchasing behavior. Thus, $\mathrm{H} 3$ and $\mathrm{H} 4$ do not find support. 
For H5-H7, a one-way between-groups analysis of variance is conducted to see if the responses to 'company $\mathrm{XY}$ is a sustainable company' differ (Table 6). There is a significant difference at $p<0.01$ between the four groups: $\mathrm{F}(3,125)=4.3, p=0.006$. The result supports $\mathrm{H} 5$. The post-hoc test shows that the significant differences are between the country combinations (2) and (3) (0.014), as well as (2) and (4) (0.011). Looking at the mean plots, it is interesting that country combination (2) has the highest mean score $(\mathrm{M}:(2)=2.13 ;(1)=1.68 ;(3)=1.48 ;(4)=1.47)$, meaning that the group with the lowest spatial distance, for the focal company as well as supplier, receives on average better results for the perception of the company's sustainability than combinations with higher distance, which supports $\mathrm{H} 6$ and H7. Additionally, the partial eta squared effect size is calculated to show how strongly the independent variable can explain the variance of the dependent variable. According to Cohen [53], there is a small effect at 0.01 , a medium effect at 0.06 and a large effect at 0.14 . This analysis shows an effect of 0.0936 or $9 \%$, resulting in a medium to large effect.

Table 6. ANOVA Results.

\begin{tabular}{cccccc}
\hline \multicolumn{7}{c}{ 'Company XY Is a Sustainable Company' } \\
\hline & Sum of Squares & df & Mean Square & F & Sig. \\
\hline Between Groups & 8945 & 3 & 2982 & 4301 & 0.006 \\
Within Groups & 86,652 & 125 & 693 & & \\
Total & 95,597 & 128 & & & \\
\hline
\end{tabular}

Finally, a linear regression helps to test H8. The country of the supplier and the focal company are tested separately to detect possible differences. None of the $\mathrm{R}^{2}$ values explain more than $9 \%$ of the variance in the models. Looking at the output summary in Table 7, no significant results are found, and therefore, $\mathrm{H} 8$ cannot be supported.

Table 7. Results linear regression (significant at $p<0.05 ; \mathrm{FC}=$ focal company).

\begin{tabular}{cccccc}
\hline Group & Country of & $\mathbf{R}$ & $\mathbf{R}^{\mathbf{2}}$ & B (Constant) & B (Independent Variable) \\
\hline \multirow{2}{*}{1} & FC & 0.053 & 0.003 & 1.587 & 0.036 \\
& Supplier & 0.189 & 0.036 & 1.149 & 0.146 \\
\hline \multirow{2}{*}{2} & FC & 0.3 & 0.09 & 0.903 & 0.444 \\
& Supplier & 0.199 & 0.039 & 0.913 & 0.337 \\
\hline \multirow{2}{*}{3} & FC & 0.183 & 0.034 & 1.016 & 0.148 \\
& Supplier & 0.132 & 0.017 & 1.200 & 0.133 \\
\hline \multirow{2}{*}{4} & FC & 0.186 & 0.035 & 1.939 & $(-) 0.186$ \\
& Supplier & 0.004 & 0.000 & 1.462 & 0.003 \\
\hline
\end{tabular}

\section{Discussion}

This study puts forward eight hypotheses, out of which three can be supported. Two can only be supported for some groups and three do not show significant results (Table 8). H1 examines a possible impact of the consumer's assessment of a company's sustainability on his/her willingness to continue buying from that firm. A significant impact is found for all the groups, except country combination (3), which is the combination of highest psychic distances for focal company and supplier, Japan_Indonesia. Here, only marginal support can be found. $\mathrm{H} 2$ looks at a possible impact of the consumer's assessment of a company's sustainability on his/her willingness to pay a price premium for sustainable products. Only country combination (4), Spain_Indonesia, receives marginal support, while the null hypothesis cannot be rejected for the other groups. These results support the theory that consumers show stronger loyalty for companies of lower distance. It might be due to a lack of trust for foreign businesses and products as well as the inability to identify with the issues [35,36]. However, one needs to differentiate 
between the two customer purchasing behavior items (CPu1-CPu2). On average, people are not willing to continue buying from the company, but would consider paying a price premium if the company started selling sustainable products. This shows there is a general interest in and activism for sustainability, which is also supported by the motivation to share the information about unsustainable production with friends and family. The answers also support the hypothesis that customers are more tolerant towards local than foreign countries and companies. When asked whether they prefer local over foreign products, respondents agree on average. The same is true for trusting local products more than foreign ones and while considering local products to be more sustainable.

Table 8. Hypothesis Results.

\begin{tabular}{cccccc}
\hline Hypothesis & $\mathbf{( 1 )}$ & $\mathbf{( 2 )}$ & $\mathbf{( 3 )}$ & $\mathbf{( 4 )}$ & Tested between Groups \\
\hline H1 & Yes & Yes & Yes (marginal) & Yes & \\
H2 & No & No & No & Yes (marginal) & \\
H3 & No & No & No & No & \\
H4 & No & No & No & No & Yes \\
H5 & & & & & Yes \\
H6 & & & & No \\
H7 & & & No & No & \\
H8 & No & No & No & \\
\hline
\end{tabular}

Legend: (1): Japan_Germany; (2): Spain_Germany; (3): Japan_Indonesia; (4): Spain_Indonesia.

Customer interest in sustainability seems to have no moderating effect on the relationship between their company perception and the willingness to continue buying from that brand (H3). This seems to be contradictory to the results of Sen and Bhattacharya [38] who claim that customer interest in a topic strengthens their support for a CSR initiative, thus showing an impact by customer interest. A closer look at the mean answers shows that respondents of country combination (3) were the most indifferent to customer interest items (ranging from 3.71 to 3.97). This seems to indicate that customers care less about countries of high psychic distance. However, responses to customer interest in country combinations (1), (2), and (4) do not vary greatly, and therefore, this interpretation should be tested again in a more detailed research about customer interest in sustainability.

To summarize the first four hypotheses, perceived company sustainability has a larger impact on the decision to continue buying products from that firm than on the willingness to pay a price premium for more sustainable products from the same company. This can be due to the fact that people who rate company $\mathrm{X}$ as very (un-)sustainable probably will (not) continue buying from that firm. The lack of a significant proof if customer perception has an impact on willingness to pay a price premium is a result of the variance in responses. On the one hand, people that have rated the firm as unsustainable and are not willing to pay a price premium might not want to support this company at all, while others might give it a chance and pay a price premium given that the company starts offering sustainable products. On the other hand, customers giving responses that score higher on customer perception are probably satisfied with the current situation and they would not see the necessity for more sustainability, thus, not willing to pay more. The inconsistency highlights once again that people have very different understandings of sustainability. However, respondents show, on average, the same interest in sustainability across all groups, therefore, customer interest does not seem to have an impact on customer perception and customer purchasing behavior.

Lastly, it is tested whether responses to customer perception significantly differ between the groups depending on the country combination to strengthen the suggested reasons for varying results in H1-H2. On the one hand, this is implicitly tested due to the four separate groups. On the other hand, respondents were directly asked to assess the countries, according to their sustainability. The first part (H5-H7) receives significant results, and thus, it can be concluded that the countries of the focal company and the supplier do influence the consumer perception of the focal company on a subliminal level. Especially in the case of low distance to both parties in country combination (2), a significant 
positive impact can be noted. Again, this supports the assumption that consumers trust more or feel more loyal to the focal company, the closer its supply chain is [35]. However, this is not necessarily because consumers think that close countries are more sustainable than distant ones. H8 does not find support in this analysis.

Although the findings did not support the perception of countries to have a significant impact on the perception of the company, the statement ' $X Y$ is a sustainable country' (on a scale from 1 to 5 , in which $1=$ strongly disagree; $5=$ strongly agree) provides some interesting results (Table 9 ). Germany receives, on average, the highest sustainability ratings [country combination (1): $M=3.62$; country combination (2): $\mathrm{M}=3.59$ ], while Indonesia is perceived as the least sustainable country out of the four [country combination (3): $M=2.13$; country combination (4): $M=2.06$ ]. The high ratings of Germany might be the result of a 'chauvinistic bias', as the majority of the respondents were German. The answers do differ depending on the country combination, e.g., Japan $[\mathrm{M}=2.47$ in country combination (1) vs. $M=3.16$ in country combination (3)]. The results show that respondents' opinions might depend on the mix of two countries instead of assessing them individually. Once again, association by guilt might play an important role. Therefore, further research regarding the contagion between countries is suggested in this field as well.

Table 9. Mean responses to country sustainability perception.

\begin{tabular}{ccccc}
\hline Group & Country & M & Min & Max \\
\hline \multirow{2}{*}{$(1)$} & Japan & 2.47 & 1 & 4 \\
& Germany & 3.62 & 1 & 5 \\
\hline \multirow{2}{*}{$(2)$} & Spain & 2.75 & 1 & 4 \\
& Germany & 3.59 & 2 & 5 \\
\hline \multirow{2}{*}{$(3)$} & Japan & 3.16 & 2 & 5 \\
& Indonesia & 2.13 & 1 & 4 \\
\hline \multirow{2}{*}{$(4)$} & Spain & 2.53 & 1 & 4 \\
& Indonesia & 2.06 & 1 & 4 \\
\hline
\end{tabular}

\section{Conclusions}

This section provides the main conclusions of the study. The theoretical contribution and managerial implications are provided in respectively Sections 6.1 and 6.2. Limitations of the study and recommendations for further research are presented in Section 6.3.

\subsection{Theoretical Contribution}

Sustainability has been widely discussed in the literature. Consumers increasingly care about sustainability and demand more transparency about the way that products have been sourced. Research has mainly looked at customers' reactions to the focal company. However, taking a look at the entire supply chain is becoming more popular. This study aims at adding the impact of country sustainability to the common company/customer effect models. Results point out that it actually does matter to the customer where the focal company and supplier are located. It highlights that in a supply chain contagion not only can the supply chain partners affect each other, but also the countries of origin can transfer their characteristics on the firms.

Customers show increasing interest in sustainability and seem to be questioning the company's activities at home and abroad. Companies need to reconsider their supplier ties and their sustainability measures to avoid suffering from association by guilt. The perceived sustainability of the country of origin of the focal company and its suppliers seem to influence customer perceptions of the focal company itself. While customers tend to perceive countries of low psychic distance as more sustainable, they also expect them to act more sustainably, and to show greater interest in local initiatives. 
This study questions the benefit of reshoring by analyzing the customers' reactions towards unsustainable corporate behavior and examining the influence of psychic distance between them and the company. The results show that in response to unsustainable behavior, customers are not willing to continue buying from that company. They are, however, generally willing to pay more for sustainable products, even if the company used to be associated with unsustainability.

\subsection{Managerial Implications}

Managerial implications can be made for the supply chain as well as the marketing side. When a supply chain scandal occurs, customers would not continue buying from the same company and would feel compelled to raise awareness. Furthermore, they trust and prefer local over foreign products, while considering them to be more sustainable. In consideration of the recent debate about reshoring, in which stockholder concerns often pursue the least costly options, these findings play an important role. Apart from the closing cost gap between Western and Eastern countries, an important incentive to re-locate is the growing demand for local products. This study suggests that being local and sustainable is closely connected in consumer perceptions and they are willing to acknowledge these efforts by paying a higher price.

For marketing purposes, the interest in sustainability seems to be the lowest when psychic distance is high, so it might be worthwhile to highlight local sustainability measures. Customers' decision to purchase products depends not only on the perceived sustainability, but also on the associated countries in the supply chain. A full reshoring of the supply chain and end-to-end sustainability might not be necessary. It is important to keep the core business local to promote trust and identification. Sustainability measures may also have the greatest effect on customer support if they aim at local problems. However, as Lii et al. [35] already warned, customers need to trust the firm and identify with the cause in order to support it, and to pay a price premium. This also leads to specific recommendations for policy makers, as they should carefully identify policies to encourage re- or near-shoring, and support local competitiveness.

\subsection{Limitations and Recommendations for Further Research}

This study also has some limitations, leading to specific recommendations for further research. Each group consisted of $>30$ participants, which is a sufficient number for the experimental set-up of this study, but in further research, larger samples would be recommended. Further, the majority of respondents in this study are Millennials. This is supported by Morgan Stanley [36], as they claim that this age group has the greatest interest in sustainability. It is therefore recommended to set up an experimental study specifically targeting other age groups as well. Another limitation is the case. While the pilot test, with and without case, did not show any significant differences between groups, the answers might differ depending on the content of the case. The topic of poultry production was chosen due to the presence in countries that are close to and distant from the respondents. As public commitment in these areas is quite new, this case might also have led to more emotional answers to the survey. Therefore, it would be interesting to compare reactions to different cases, including a larger variety of products (e.g., Clothing: [54]; Electronics: [55]).

Other future research recommendations are oriented towards the introduction of aspects of customer loyalty to the research model, such as customer satisfaction, customer value, trust, commitment, and word of mouth [56]. While this study takes into account the intention to continue buying from the focal company or the willingness to pay a price premium for sustainable products from the focal company, other issues of customer loyalty might be worthwhile to explore in the context of supply chain contagion and association by guilt.

Author Contributions: Conceptualization, C.V., W.L., L.Q. and J.S.; Formal analysis, C.V., W.L., L.Q. and J.S.; Investigation, C.V. and W.L.; Methodology, C.V. and L.Q.; Supervision, L.Q. and J.S.; Validation, C.V. and L.Q.; Writing-original draft, C.V., W.L., L.Q. and J.S.; Writing-review \& editing, W.L., L.Q. and J.S.

Funding: This research received no external funding. 
Acknowledgments: We would like to thank the four anonymous reviewers and the academic editor for their valuable feedback on previous versions of this article.

Conflicts of Interest: The authors declare no conflict of interest.

\section{Appendix A. Questionnaire for Country Combination (1) Japan_Germany}

\begin{tabular}{|c|c|c|}
\hline \multirow{2}{*}{ Personal information } & \multicolumn{2}{|l|}{ Age } \\
\hline & \multicolumn{2}{|l|}{ Nationality } \\
\hline Description of the case & \multicolumn{2}{|l|}{ See Box 1.} \\
\hline \multirow{6}{*}{$\begin{array}{l}\text { Statements concerning } \\
\text { the case }\end{array}$} & $\begin{array}{l}\text { I care about the people affected by poultry production in } \\
\text { Germany. (Case_1) }\end{array}$ & $\begin{array}{l}\text { (1 Strongly Disagree, } 2 \text { Disagree, } \\
3 \text { Neutral, } 4 \text { Agree, } 5 \text { Strongly Agree) }\end{array}$ \\
\hline & $\begin{array}{l}\text { I care about the environment affected by poultry } \\
\text { production in Germany. (Case_2) }\end{array}$ & $\begin{array}{l}\text { (1 Strongly Disagree, } 2 \text { Disagree, } \\
3 \text { Neutral, } 4 \text { Agree, } 5 \text { Strongly Agree) }\end{array}$ \\
\hline & $\begin{array}{l}\text { I care about the animals affected by poultry production } \\
\text { in Germany. (Case_3) }\end{array}$ & $\begin{array}{l}\text { (1 Strongly Disagree, } 2 \text { Disagree, } \\
3 \text { Neutral, } 4 \text { Agree, } 5 \text { Strongly Agree) }\end{array}$ \\
\hline & $\begin{array}{l}\text { [Focal Company Name] is a sustainable company. } \\
\text { (Case_4) }\end{array}$ & $\begin{array}{l}\text { (1 Strongly Disagree, } 2 \text { Disagree, } \\
3 \text { Neutral, } 4 \text { Agree, } 5 \text { Strongly Agree) }\end{array}$ \\
\hline & $\begin{array}{l}\text { I am willing to pay a price premium for [Focal Company } \\
\text { Name] products containing sustainable poultry. (Case_6) }\end{array}$ & $\begin{array}{l}\text { (1 Strongly Disagree, } 2 \text { Disagree, } \\
3 \text { Neutral, } 4 \text { Agree, } 5 \text { Strongly Agree) }\end{array}$ \\
\hline & $\begin{array}{l}\text { I feel compelled to spread the word about unsustainable } \\
\text { poultry production in Germany for [Focal Company } \\
\text { Name] products and inform my friends and family } \\
\text { about it. (Case_7) }\end{array}$ & $\begin{array}{l}\text { (1 Strongly Disagree, } 2 \text { Disagree, } \\
3 \text { Neutral, } 4 \text { Agree, } 5 \text { Strongly Agree) }\end{array}$ \\
\hline \multirow{5}{*}{$\begin{array}{l}\text { Statements concerning } \\
\text { sustainability interest }\end{array}$} & I prefer local products over foreign products. (Sust_1) & $\begin{array}{l}\text { (1 Strongly Disagree, } 2 \text { Disagree, } \\
3 \text { Neutral, } 4 \text { Agree, } 5 \text { Strongly Agree) }\end{array}$ \\
\hline & $\begin{array}{l}\text { Local products are more sustainable than foreign } \\
\text { products. (Sust_4) }\end{array}$ & $\begin{array}{l}\text { (1 Strongly Disagree, } 2 \text { Disagree, } \\
3 \text { Neutral, } 4 \text { Agree, } 5 \text { Strongly Agree) }\end{array}$ \\
\hline & $\begin{array}{l}\text { I want to know the impact that a product has on } \\
\text { sustainability. (Sust_5) }\end{array}$ & $\begin{array}{l}\text { (1 Strongly Disagree, } 2 \text { Disagree, } \\
3 \text { Neutral, } 4 \text { Agree, } 5 \text { Strongly Agree) }\end{array}$ \\
\hline & $\begin{array}{l}\text { I want to know the impact that a product has on my } \\
\text { country's sustainability. (Sust_6) }\end{array}$ & $\begin{array}{l}\text { (1 Strongly Disagree, } 2 \text { Disagree, } \\
3 \text { Neutral, } 4 \text { Agree, } 5 \text { Strongly Agree) }\end{array}$ \\
\hline & $\begin{array}{l}\text { I want to know how sustainably my product has been } \\
\text { produced. (Sust_7) }\end{array}$ & $\begin{array}{l}\text { (1 Strongly Disagree, } 2 \text { Disagree, } \\
3 \text { Neutral, } 4 \text { Agree, } 5 \text { Strongly Agree) }\end{array}$ \\
\hline \multirow[t]{2}{*}{$\begin{array}{l}\text { Statements concerning } \\
\text { country perception }\end{array}$} & [Country name] is a sustainable country. (Country_1) & $\begin{array}{l}\text { (1 Strongly Disagree, } 2 \text { Disagree, } \\
3 \text { Neutral, } 4 \text { Agree, } 5 \text { Strongly Agree) }\end{array}$ \\
\hline & [Country name] is a sustainable country. (Country_2) & $\begin{array}{l}\text { (1 Strongly Disagree, } 2 \text { Disagree, } \\
3 \text { Neutral, } 4 \text { Agree, } 5 \text { Strongly Agree) }\end{array}$ \\
\hline
\end{tabular}

\section{References}

1. Prahalad, C.K.; Hamel, G. Strategy as a field of study: Why search for a new paradigm? Strateg. Manag. J. 1994, 15, 5-16. [CrossRef]

2. Ortas, E.; Moneva, J.M.; Álvarez, I. Sustainable supply chain and company performance: A global examination. Suppl. Chain Manag. Int. J. 2014, 19, 332-350. [CrossRef]

3. Ashby, A. From global to local: Reshoring for sustainability. Oper. Manag. Res. 2016, 9, 1-14. [CrossRef]

4. Gualandris, J.; Golini, R.; Kalchschmidt, M. Do supply management and global sourcing matter for firm sustainability performance? An international study. Suppl. Chain Manag. Int. J. 2014, 19, 258-274. [CrossRef] 
5. Molet, M.; Stagner, J.P.; Miller, H.C.; Kosinski, T.; Zentall, T.R. Guilt by association and honor by association: The role of acquired equivalence. Psychon. Bull. Rev. 2013, 20, 385-390. [CrossRef] [PubMed]

6. Bastian, J.; Zentes, J. Supply chain transparency as a key prerequisite for sustainable agri-food supply chain management. Int. Rev. Retail. Distrib. Consum. Res. 2013, 23, 553-570. [CrossRef]

7. Johnsen, T.E.; Howard, M.; Miemczyk, J. Purchasing and Supply Chain Management: A Sustainability Perspective; Routledge: New York, NY, USA, 2014; ISBN 9780415690881.

8. EY. Sustainability Reporting — The Time Is Now; Ernst \& Young Global Limited: London, UK, 2014.

9. Quarshie, A.M.; Salmi, A.; Leuschner, R. Sustainability and corporate social responsibility in supply chains: The state of research in supply chain management and business ethics journals. J. Purch. Suppl. Manag. 2016, 22, 82-97. [CrossRef]

10. Ahi, P.; Searcy, C. A comparative literature analysis of definitions for green and sustainable supply chain management. J. Clean. Prod. 2013, 52, 329-341. [CrossRef]

11. Seuring, S. Assessing the rigor of case study research in supply chain management. Suppl. Chain Manag. Int. J. 2008, 13, 128-137. [CrossRef]

12. Seuring, S.; Müller, M. From a literature review to a conceptual framework for sustainable supply chain management. J. Clean. Prod. 2008, 16, 1699-1710. [CrossRef]

13. Elkington, J. Cannibals with Forks: The Triple Bottom Line of the 21st Century; New Society: Stoney Creek, CT, USA, 1998; ISBN 9780865713925.

14. Carter, C.R.; Rogers, D.S. A framework of sustainable supply chain management: Moving toward new theory. Int. J. Phys. Distrib. Logist. Manag. 2008, 38, 360-387. [CrossRef]

15. Pagell, M.; Shevchenko, A. Why research in sustainable supply chain management should have no future. J. Suppl. Chain Manag. 2014, 50, 44-55. [CrossRef]

16. Pagell, M.; Wu, Z. Building a more complete theory of sustainable supply chain management using case studies of 10 exemplars. J. Suppl. Chain Manag. 2009, 45, 37-56. [CrossRef]

17. Friedman, M. The Social Responsibility of Business is to Increase its Profits. The New York Times Magazine, 13 September 1970.

18. Xie, Y. The effects of corporate ability and corporate social responsibility on winning customer support: An integrative examination of the roles of satisfaction, trust and identification. Glob. Econ. Rev. 2014, 43, 73-92. [CrossRef]

19. Butler, S. Primark to pay £6m more to victims of Rana Plaza factory in Bangladesh. Guardian, 16 March 2014. Available online: http:/ / bit.ly/2Avsp8L (accessed on 8 May 2018).

20. Khuntia, J.; Sun, H.; Yim, D. Sharing news through social networks. Int. J. Media Manag. 2016, 18, 59-74. [CrossRef]

21. McWilliams, A.; Parhankangas, A.; Coupet, J.; Welch, E.; Barnum, D.T. Strategic decision making for the Triple Bottom Line. Bus. Strateg. Environ. 2016, 25, 193-204. [CrossRef]

22. Bhalla, A.; Sodhi, M.S.; Son, B.-G. Is more IT offshoring better? An exploratory study of western companies offshoring to South East Asia. J. Oper. Manag. 2008, 26, 322-335. [CrossRef]

23. Ellram, L.M.; Tate, W.L.; Billington, C. Offshore outsourcing of professional services: A transaction cost economics perspective. J. Oper. Manag. 2008, 26, 148-163. [CrossRef]

24. Gurtu, A.; Searcy, C.; Jaber, M.Y. A framework for reducing global manufacturing emissions. J. Environ. Dev. 2016, 25, 159-190. [CrossRef]

25. Oguamanam, C. Sustainable development in the era of bioenergy and agricultural land grab. Int. Environ. Law Glob. South 2015, 237-255.

26. Menhat, M.N.S.; Ariffin, M.K.A.; Sulaiman, S.; Tang, S.H. Managing uncertainty in supply chain management of vessel chartering in oil and gas industry. Appl. Mech. Mater. 2014, 564, 694-699. [CrossRef]

27. Zeleny, M. The mobile society: Effects of global sourcing and network organisation. Int. J. Mob. Learn. Organ. 2007, 1, 30-40. [CrossRef]

28. Goodwill, D.; Goodwill, O. From offshoring to reshoring-Bringing manufacturing back to North America and the impact on supply chain strategies. Can. Transp. Logist. 2012. Available online: http://bit.ly/ 2hXZTom (accessed on 8 May 2018).

29. Tate, W.L. Offshoring and reshoring: US insights and research challenges. J. Purch. Suppl. Manag. 2014, 20, 66-68. [CrossRef] 
30. Joubioux, C.; Vanpoucke, E. Towards right-shoring: A framework for off-and re-shoring. Oper. Manag. Res. 2016, 9, 117-132. [CrossRef]

31. Choi, T.-M. Local sourcing and fashion quick response system: The impacts of carbon footprint tax. Trans. Res. Part E Logist. Trans. Rev. 2013, 55, 43-54. [CrossRef]

32. Arıkan, E.; Jammernegg, W. The single period inventory model under dual sourcing and product carbon footprint constraint. Int. J. Prod. Econ. 2014, 157, 15-23. [CrossRef]

33. Milne, M.J.; Gray, R. W(h)ither ecology? The Triple Bottom Line, the Global Reporting Initiative, and corporate sustainability reporting. J. Bus. Eth. 2013, 118, 13-29. [CrossRef]

34. Chernev, A.; Blair, S. Doing Well by Doing Good: The Benevolent Halo of Corporate Social Responsibility. J. Consum. Res. 2015, 41, 1412-1425. [CrossRef]

35. Lii, Y.-S.; Wu, K.-W.; Ding, M.-C. Doing good does good? Sustainable marketing of CSR and consumer evaluations. Corp. Soc. Responsib. Environ. Manag. 2013, 20, 15-28. [CrossRef]

36. Morgan Stanley. Sustainable Signals: The Individual Investor Perspective. Morgan Stanley Institute for Sustainable Investing. 2015. Available online: www.morganstanley.com/sustainableinvesting/pdf/ Sustainable_Signals.pdf (accessed on 15 April 2018).

37. Homburg, C.; Stierl, M.; Bornemann, T. Corporate social responsibility in business-to-business markets: How organizational customers account for supplier corporate social responsibility engagement. J. Mark. 2013, 77, 54-72. [CrossRef]

38. Sen, S.; Bhattacharya, C. Does Doing Good Always Lead to Doing Better? Consumer Reactions to Corporate Social Responsibility. J. Mark. Res. 2001, 38, 225-243. [CrossRef]

39. Friedl, G.; Wagner, S.M. Supplier development or supplier switching? Int. J. Prod. Res. 2012, 50, 3066-3079. [CrossRef]

40. Johanson, J.; Vahlne, J.-E. The internationalization process of the firm-A model of knowledge development and increasing foreign commitment. J. Int. Bus. Stud. 1977, 8, 23-32. [CrossRef]

41. Mol, M.J.; Pauwels, P.; Matthyssens, P.; Quintens, L. A technological contingency perspective on the depth and scope of international outsourcing. J. Int. Manag. 2004, 10, 287-305. [CrossRef]

42. Neumayer, E. The human development index and sustainability-A constructive proposal. Ecol. Econ. 2001, 39, 101-114. [CrossRef]

43. SSF (Sustainable Society Foundation). Results 2014; SSF: The Hague, The Netherlands, 2015. Available online: http:/ / bit.ly/2AwqaSs (accessed on 8 May 2018).

44. Vachon, S. International operations and sustainable development: Should national culture matter? Sustain. Dev. 2010, 18, 350-361. [CrossRef]

45. Lopez, C.; Balabanis, G. A Model Linking Corporate Brand, Industry Image and Country of Origin Image. In Looking Forward, Looking Back: Drawing on the Past to Shape the Furture of Marketing, Proceedings of the 2013 World Marketing Congress, Melbourne, Australia, 17-20 July 2013; Springer: Berlin/Heidelberg, Germany, 2015.

46. Brienen, M.; Cavenagh, B.; Vliet, W.V.; Copier, M. Meeting the Challenge of Indonesia's Growing Demand for Poultry. 2014. Available online: http:/ / bit.ly/2ztx2C6 (accessed on 8 May 2018).

47. Klawitter, N. Germany's Chicken Wars: The Controversial Practices of Poultry Mega-Factories. Spiegel, 2011. Available online: http:/ / bit.ly/2yLcIgc (accessed on 8 May 2018).

48. Pallant, J. SPSS Survival Manual; McGraw-Hill Education: Berkshire, UK, 2013.

49. Field, A. (Ed.) Regression. In Discovering Statistics Using SPSS, 3rd ed.; Sage: Thousand Oaks, CA, USA, 2009; pp. 197-209.

50. Bortz, J.; Lienert, G.A.; Boehnke, K. (Eds.) Zusammenhangsmaße und Regression. In Verteilungsfreie Methoden in Der Biostatistik, 3rd ed.; Springer: Berlin/Heidelberg, Germany, 2008; pp. 325-448.

51. Kaiser, H. An index of factorial simplicity. Psychometrika 1974, 39, 401-415. [CrossRef]

52. Bartlett, M.S. A note on the multiplying factors for various chi square approximations. J. R. Stat. Soc. 1954, 16, 296-298.

53. Cohen, J.W. Statistical Power Analysis for the Behavioral Sciences, 2nd ed.; Lawrence Erlbaum: Associates Hillsdale, NJ, USA, 1988.

54. Osibanjo, O.; Nnorom, I.C. The challenge of electronic waste (e-waste) management in developing countries. Waste Manag. Res. 2007, 25, 489-501. [CrossRef] [PubMed] 
55. Freise, M.; Seuring, S. Social and environmental risk management in supply chains: A survey in the clothing industry. Logist. Res. 2015, 8, 1-12. [CrossRef]

56. Russo, I.; Confente, I. Customer Loyalty and Supply Chain Management. Business-to-Business Customer Loyalty Analysis; Routledge: London, UK, 2017. 